\title{
Apresentação
}

\section{Movimentos sociais e democracia}

\begin{abstract}
A associação de movimentos sociais e democracia para intitular esta edição da Civitas pode parecer a junção de um tema de ontem com uma questão muito atual. De fato, as ciências sociais vêm se ocupando, há anos, muito mais com a democracia e seu funcionamento do que com os movimentos sociais que articulem coletivamente questionamentos à ordem social dada. Com a proposição desta temática, o que se pretende é recolocar a questão do lugar dos movimentos sociais na democracia, e oferecer algumas pistas para sua discussão. Estas pistas são esboçadas tanto através da análise de autores clássicos como da pesquisa e reflexão a respeito de práticas sociais contemporâneas. Os dez textos aqui reunidos perfazem uma trajetória entre releituras de autores consagrados, pesquisa e reflexão sobre práticas sociais próprias ou de terceiros ainda em curso e o retorno ao refinamento conceitual.
\end{abstract}

Civitas, Porto Alegre, v. 4, n 1, jan.-jun. 2004 
No texto Movimentos sociais e a construção do Político, Hans-Georg Flickinger traz uma contribuição ao atual debate sobre movimentos sociais amparado no pensamento de Carl Schmitt. Para ele, os movimentos sociais, ao assumirem o confronto permanente entre as temáticas legalmente confirmadas e as demandas utópicas, podem recuperar o verdadeiro espaço do Político assumindo-se ser voz daqueles que são ignorados pela política institucionalizada. A base da argumentação é uma releitura do opúsculo de Carl Schmitt Staat, Bewegung, Volk (Estado, movimento, povo), publicado em 1933. Com isto o autor dá continuidade a sua crítica à ordem social liberal moderna, da qual resultou, entre outros, publicado em 2003, pela Edipucrs, o livro Em nome da liberdade.

Em afinidade com esta linha de raciocínio, Luiz Vicente Vieira se apóia em Rousseau e Schmitt para tematizar o liberalismo. Ele argumenta, em seu texto a recuperação do espaço autônomo do Político, que, enquanto a corrente liberal fundamenta o estado num contrato que pressupõe uma igualdade formal-jurídica e necessita do parlamento como o lugar de negociação dos diferentes interesses presentes na sociedade, Rousseau e Schmitt partem do pressuposto da existência de uma homogeneidade substancial pré-contratual na sociedade. No primeiro autor ela se expressará como vontade geral; no segundo como unidade política. Os novos movimentos sociais, que igualmente se apóiam em pressupostos de unidade substantiva, submetem hoje a estrutura política apoiada no liberalismo a permanentes questionamentos de sua legitimidade.

A dimensão normativa da globalização dentro da transição brasileira para a democracia é analisada por Nythamar de Oliveira em seu texto Globalização e democratização no Brasil: uma interpretação do liberalismo político de Rawls, buscando encontrar na recepção brasileira do liberalismo político de Rawls uma contribuição para uma teoria da justiça global. $\mathrm{O}$ autor advoga por uma idéia de razão pública que subscreva tanto a um ethos autônomo, deliberativo, para a ação local, quanto a uma concepção universalizável, igualitária, de justiça e liberdade. Na tradição de Rawls, Oliveira busca reformular a idéia rawlsiana de autonomia pública e democracia deliberativa para dentro do contexto brasileiro - uma sociedade cujas instituições ainda estão em processo de consolidação.

Fechando um primeiro conjunto de textos com ênfase mais propriamente teórica, Neiva Afonso de Oliveira, em Propriedade e contrato social: um breve incurso no relacionamento entre Estado e Associações de Trabalhadores a partir de C. B. Macpherson, resgata a análise deste autor sobre uma etapa histórica decisiva na transformação gradual do movimento dos trabalhadores na Grã-Bretanha numa instituição política. Ao mesmo 
tempo em que nos mostra esta importante transição num movimento social, ao analisar a tese apresentada em 1935 e ainda inédita, a autora traz à tona facetas do desenvolvimento intelectual do jovem Macpherson pouco conhecidas entre nós.

As próximas duas contribuições têm como foco experimentos de participação que vêm sendo desenvolvidos no Brasil. Washington Luís de Sousa Bonfim, em seu texto $O$ aprofundamento da democracia no Brasil: tendências, conflitos e dinâmica recente, trata da disjuntiva entre representação e participação na democracia no Brasil. Para tanto, ele analisa os conselhos de gestores e o orçamento participativo assim como a crescente judicialização da política, apoiando-se teoricamente no conceito de soberania complexa. $\mathrm{O}$ autor mostra como a relação entre estado e sociedade vem mudando na medida em que a democracia representativa é aprofundada e novos mecanismo de participação na vida política são criados, e como isto se reflete na compreensão que aqui temos de cidadania.

Em Orçamento participativo: conciliando direitos sociais de cidadania e legitimidade do governo, Emil A. Sobottka busca reconstituir a trajetória da implementação do Orçamento Participativo em Porto Alegre sob a ótica da tensão, vivida pela Frente Popular, entre o mandato recebido dos seus eleitores e a tentativa de ampliação da legitimidade enquanto governo local. Além de equacionar favoravelmente a questão da legitimidade, para o autor os governantes patrocinaram naquela cidade a constituição coletiva de um incipiente espaço político que se poderia denominar um processo de cidadania local. Este processo de cidadania certamente está distante da autonomia do Político propugnada por Carl Schmitt, e comentado nos textos de Flickinger e Vieira, mas representa uma inovação na democracia de nosso País a partir de um contexto politicamente adverso.

O contexto maior onde hoje se busca inovar e a profundar a democracia está marcado pela globalização de cunho econômico-liberal. A despeito de uma discreção bem maior do que há pouco mais de uma década, a resistência criativa de movimentos sociais segue presente, influi nas políticas públicas e desafia a atuação daqueles que constituem sua identidade profissional vinculados ao atendimento de demandas sociais. Os três textos que seguem fazem eco a esta realidade.

Nadia Lucia Fuhrmann, em sua contribuição intitulada Neoliberalismo, cidadania e saúde: a recente reorganização do sistema público de saúde no Brasil, mostra como o sistema público de saúde em implantação no Brasil, contrariando a lógica neoliberal da globalização e a própria percepção majoritária expressa no senso comum, mantém um caráter de universalidade, eqüidade e integralidade, e incentiva a participação e o 
controle sociais desta política pelos cidadãos. Ele reflete ainda a mobilização do movimento pela saúde. Na interpretação da autora, a própria lógica liberal, de internalizar os conflitos na sociedade civil e descentralizar as políticas públicas, contribuiu para a configuração de um sistema que trata o cuidado à saúde antes como um direito de cidadania para todo o cidadão brasileiro do que como mercadoria.

A relação entre os movimentos sociais críticos da globalização e o Serviço Social é colocada em discussão no texto Serviço Social $e$ movimentos sociais - uma não-relação?, de Leonie Wagner. Sua base de referência é a história do desenvolvimento da profissão de assistente social na Alemanha. Diferente do que tem acontecido no movimento pela saúde no Brasil, onde profissionais e movimentos sociais lograram alianças relativamente bem-sucedidas, a relação entre o Serviço Social e os movimentos sociais na Alemanha tem sido e continuam tênues - quase uma não-relação. $\mathrm{Na}$ visão da autora, eles não compreenderam ainda o potencial de uma aliança estratégica, a despeito de uma grande proximidade histórica em seus objetivos.

O aprendizado político é o centro da reflexão de Rosalvo Schütz em seu texto Potencialidades pedagógicas dos movimentos sociais populares. $\mathrm{O}$ autor vale-se de uma longa experiência com movimentos sociais de resistência ao sistema capitalista vigente e das possibilidades abertas pelo distanciamento e a imersão na atividade mais reflexiva que o doutorado no exterior permitem, para perscrutar o potencial pedagógico dos movimentos socias populares na construção de novas identidades pessoais, na explicitação das estruturas de poder e na fundamentação de novas práticas políticas.

Por fim, como que para fechar o círculo, novamente um texto de cunho prioritariamente teórico. Em Sobre o alcance teórico do conceito "exlusão", Avelino da Rosa Oliveira analisa criticamente a trajetória do conceito de exclusão social e mostra como um termo impreciso entra em moda, faz carreira na academia até ser aceito como auto-evidente, e na política, até tornar-se palavra-chave de propostas políticas. O autor mostra as diferentes acepções, o limitado alcance explicativo, para sugerir um lugar para o conceito de exclusão na análise e práxis social em três níveis: como conceito descritivo, como conceito interpretativo e, finalmente, como conceito operativo. No contexto de uma teoria social mais ampla, segundo Oliveira, o conceito poderia ter um lugar na manifestação de tramas sociais não perceptíveis ao primeiro olhar. 
Com a organização desta coletânea de textos para Civitas, nossa expectativa é poder ter contribuído para lançar renovados olhares sobre clássicas questões: a lógica que subjaz à realidade da democracia atual, os protagonistas de sua dinâmica e as categorias teóricas que dêem consistência a estes olhares.

Hans-Georg Flickinger

Emil A. Sobottka 